J. Clin. Chem. Clin. Biochem.

Vol. 20, 1982, pp. 735-744

\title{
Zur Bestimmung der Aktivität der Lipase mit dem sogenannten turbidimetrischen Test
}

\author{
Von W. Rick und M. Hockeborn
}

Institut für Klinische Chemie und Laboratoriumsdiagnostik der Universität Düsseldorf

(Eingegangen am 1. Oktober/14. Dezember 1981)

Zusammenfassung: Im sogenannten turbidimetrischen Test zur Bestimmung der Lipase im Serum dient die Abnahme der Trübung einer Triolein-Emulsion als Meßgröße. Die von Ziegenhorn et al. ((1979) Clin. Chem. 25, 1067) beschriebene Modifikation mit Zusatz von Colipase und Auswertung über einen Enzymstandard wurde geprüft.

Die bisher nicht gelösten optischen Probleme, die bei Trübungsmessungen mittels eines Photometers auftreten, seien besonders hervorgehoben. Während die enzymatische Reaktion bei Einsatz von Enzymstandard geradlinig verlief und entsprechend der Vorschrift zwischen der 4. und 9. Minute nach Start auswertbar war, zeigte im Gegensatz dazu ein Teil der untersuchten Proben keinen geradlinigen Abfall des Meßsignals in der vorgeschriebenen Zeitspanne. Andere Proben ergaben eine konstante Anzeige oder sogar eine Trübungszunahme, die sich z.T. durch Lagerung der Seren änderte. Neben der enzymatischen Reaktion laufen in diesen Ansätzen offenbar Veränderungen an Serumbestandteilen ab, die zu einem Anstieg der Trübung füren; jede Probe zeigt praktisch eine eigene Kinetik. Analysiert man Verdünnungen von Seren mit hoher katalytischer Aktivität an Lipase in physiologischer NaCl-Lösung, so findet sich insbesondere bei frisch gewonnenen Proben keine geradlinige Beziehung zwischen eingesetzter Enzymmenge und Trübungsabnahme. Die Eṛgebnisse der Ǔntersuchungen von 107 Seren mit dem sogenannten turbidimetrischen Test unterscheiden sich signifikant von den mit der titrimetrischen Methode ermittelten Resultaten ( $P$ im Wilcoxon-Test $<0,0001$; $r=0,87$ ). Auf die wichtigsten Probleme, die noch zu lösen sind, damit im Einzelfall mit dem sogenannten turbidimetrischen Test diagnoștisch aussagekräftige Befunde erzielt werden, wird hingewiesen.

\section{Determination of lipase by the turbidimetric method}

Summary: The turbidimetric determination of lipase in serum is performed by measuring the decrease in turbidity of a triolein emulsion. The modification of Ziegenhorn et al. ((1979) Clin. Chem. 25, 1067) with addition of colipase and evaluation via an enzyme stàndard was tested.

The hitherto unresolved optical problems that accompany turbidity measurements with a photometer are especially pronounced. The reaction with enzyme standard gave a linear response and, in accordance with the literature, could be used for evaluation between the 4 th. and 9 th. minute after start of the reaction. In contrast, some of the serum samples showed no linear measurement response in this time period. Other samples gave a constant signal, or even showed a decrease in turbidity, which varied to some extent with the storage of the sera. In these assay mixtures it appears that the enzymic reaction is accompanied by changes in serum components, which lead to an increase in turbidity; practically every sample shows different kinetics. Addition to the assay mixture of different dilutions of high lipase sera in physiological saline does not result in a linear relationship between the quantity of added enzyme and the decrease in turbidity; this is especially true of sera from fresh blood. The results of the turbidimetric assay of 107 sera differ significantly from those obtained by the titrimetric method $(\mathrm{P}$ in the Wilcoxon test $<0.0001 ; \mathrm{r}=0.87)$. The main problems of the turbidimetric asșay, which must be solved in order to obtain diagnostically useful results from individual tests, are identified.

\section{Einfiihrung}

Die Bestimmung der katalytischen Aktivität der Lipase im Serum mit Triolein bzw. Olivenöl als Substrat führt nur dann zu reproduzierbaren und klinisch relevanten Ergebnissen, wenn unter optimalen Bedingungen die
Anfangsgeschwindigkeit der Reaktion durch kontinuierliche Titration: der freigesetzten Fettsäuren gemessen wird. Aufgrund der normalerweise im Serum enthaltenen sehr niedrigen Aktivitäten werden außerordentlich empfindliche Meß- und Regelgeräte benötigt, deren Auf- 
lösungsvermögen etwa 0,001 pH-Einheiten - entsprechend einer Potentialdifferenz von etwa $50 \mu \mathrm{V}$ - betragen muß. Auch der übrige technische Aufwand ist erheblich. So müssen die Ansätze mit $0,01 \mathrm{~mol} / 1$ Lauge titriert und ständig mit Kohlendioxid-freiem Stickstoff gespült werden. Alle Methoden bzw. Modifikationen, die als Zweipunktverfahren durch Verlängerung der Inkubationszeit diesen Aufwand zu umgehen suchen, führen nicht zu korrekten Ergebnissen, da die Reaktionsgeschwindigkeit während der üblicherweise angegebenen Inkubationszeiten von 3-24 Stunden nicht konstant bleibt.

Da Photometer allgemein verfuigbar sind, wurde mehrfach versucht, die katalytische Aktivität von Lipase zu messen, indem die Abnahme der Trübung einer Substratemulsion verfolgt wird. Wir untersuchten die auf diesem Prinzip beruhende Modifikation von Ziegenhorn et al. (1).

\section{Material und Methodik}

\section{Reagens}

Zur Bestimmung der Lipase wurde die im Handel befindliche Reagentien-Kombination Lipase, Boehringer Mannheim, Bestell-Nr. 263346 verwendet. Als Endkonzentration im Test werden angegeben:

$\begin{array}{lcc}\text { Triolein } & 0,30 \mathrm{mmol} / 1 \\ \text { Tris-Puffer } & 26 & \mathrm{mmol} / 1 \\ \text { Na-desoxycholat } & 19 & \mathrm{mmol} / 1 \\ \mathrm{CaCl}_{2} & 0,1 & \mathrm{mmol} / \mathrm{l} \\ \text { Colipase } & 3,0 & \mathrm{mg} / \mathrm{l}\end{array}$

Der pH-Wert beträgt 9,2.

Das Reagens enthält weiterhin Harnstoff, ein „Schutzkolloid“ (Mannit, Rinderserumalbumin, Polyethylenglykol, Polyvinylpyrrolidon o.ä.) (2) und Natriumazid als Konservierungsmittel. Angaben des Herstellers zur Art des „Schutzkolloids“ und zu den Konzentrationen dieser zusätzlichen Substanzen fehlen.

\section{Enzyme}

Die folgenden Enzympräparationen wurden eingesetzt:

Lipase (Triacylglycerol acyl hydrolase, EC 3.1.1.3), gereinigte Pankreaslipase aus menschlichem Duodenalsaft; katalytische Aktivität $690 \mathrm{U} / \mathrm{mg}\left(25^{\circ} \mathrm{C}\right)$ gegen Triolein als Substrat.

„Lipase-Standard“" aus der Reagentien-Kombination Lipase, das Präparat wurde nach Vorschrift aufgelöst; Sollwertangaben in Abhängigkeit von der Charge.

Probenmaterial

Bei den verwendeten Proben handelte es sich um: Seren von Gesunden,

Seren von Patienten mit akuten oder chronischen Pankreaserkrankungen,

Seren, die etwa 10 Minuten nach i.v. Injektion von 5000 I.E. Heparin von Gesunden gewonnen wurden,

Seren, in denen die Pankreaslipase durch zweistïndige Inkubation bei $56^{\circ} \mathrm{C}$ vollständig inaktiviert worden war; dies wurde im titrimetrischen Test mit Triolein als Substrat nachgewiesen.

\section{Verfahren}

\section{Prinzip}

Von Ziegenhorn et al. (3) wird folgender Reaktionsablauf angegeben:

„Triolein $+2 \mathrm{H}_{2} \mathrm{O} \stackrel{\text { Lipase }}{\longrightarrow}$ Monoglycerid + 2 Mol Fettsäuren“
Die Trübung der Triolein-Emulsion nimmt infolge der Hydrolyse des Substrats ab. Dadurch ergibt sich eine Zunahme der Lich tdurchlässigkeit des Testansatzes, die im UV-Bereich besonders ausgeprägt ist. Das Meßsignal wird am Photometer auf der Absorptionsskala abgelesen.

\section{Ausführung}

i 1

Reagens und Enzymstandard wurden nach Vorschrift des Herstellers aufgelöst. Da das Auffüllen des lyophilisierten LipaseReagens in den weitlumigen Originalfläschchen bis zu der angebrachten Markierung nicht zu einem ausreichend exakten Endvolumen führen kann, die Ergebnisse andererseits über einen Enzymstandard berechnet werden, wurde für jẹde Serie der gelöste Inhalt einer genügenden $Z$ ahl von Fläschchen vor Gebrauich gemischt. Für jede Analysenreihe wurde so eine konstante Substratkonzentration im Testansatz gesichert und dadurch eine Berechnung über die mitgeführten Standardwerte ermöglicht.

Da das zeitraubende Mischen der Ansätze in Küvetten leicht zur Schlierenbildung und zu Verunreinigungen führen kann, wurden jeweils $2,5 \mathrm{ml}$ Substratiösung in Reagensröhrchen auf $25^{\circ} \mathrm{C}$ temperiert. Nach Zugabe von $100 \mu$ l Probe; sorgfailtigem Mischen unter Vermeidung von Schaumbildung und Ửberführen des Ansatzes in eine Küvette im auf $25^{\circ} \mathrm{C}$ temperierten Küvettenhalter wurde das Meßsignal bei $365 \mathrm{~nm}$ im Spektrallinienphotometer (Eppendorf Digitalphotometer 6115 mit Küvettenwechseleinrichtung 2705) - abweichend von der Herstellervorschrift - in Minutenabständen, z.T. bis zu 25 Minuten lang, auf der Absorptionsskala abgelesen. In jeder Serie wurden Reagentien-Leerwerte mit physiologischer $\mathrm{NaCl}$-Lösung und Standardwerte mit Enzymstandard anstelle der Probe angesetzt. Ebenso wurden Kontrollproben mitgeführt.

\section{Berechnung}

Wie im Abschnitt ,Ergebnisse “ im einzelnen beschrieben ist, fand sich bei den verschiedenen Proben eine geradlinige Anderung des Meßsignals pro Minute zư ganż unterschiedlichen Zeiteñ nach Beginn der Reaktion. Zur Auswertung kann daher nicht - wie vom Hersteller angegeben - regelmäßig die Änderung der „Extinktion" zwischen der 4. und der 9. Minute nach Start herangezogen werden. Wir bildeten aus den Ablesungen pro Minute im linearen Reaktionsverlauf einen Durchschnittswert - wegen der Unempfindlichkeit des Verfahrens mit 4 Nachkommastellen - und setzten ihn in folgende Formel eiñ:

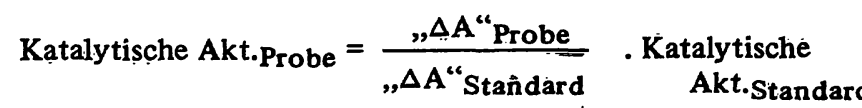

\section{Ergebnisse}

\section{Reagentien-Leerwert}

Ünter den Testbedingungen fand sich in Abwesenheit von Lipase keine spontane Verminderung der Trübungsintensität, so daß bei der Auswertung der Messungen kein Reagentien-Leerwert zu berücksichtigen ist.

\section{Enzymstandard}

Während bei der Analyse des Enzymstandards unter Verwendung der gleichen Substratemulsion gut reproduzierbare Meßßsignale erhalten wurden (Variations: koeffizient in der Serie $=1,9 \%$ ), ergaben sich mit Triolein-Emulsionen der gleichen Charge, die jedoch zu verschiedenen Zeiten aufgelöst wurden, zum Teil stark unterschiedliche Ergebnisse. Bei unseren Untersuchungen schwankten die Werte für das , , $\Delta \mathrm{A}$ " p pro 5 Minuten am gleichen Photometer unter Verwendung einer justierten 
Küvettenwechseleinrichtung zwischen 0,050 und 0,083 . $\mathrm{Da}$ diese Differenzen nicht den Eigenschaften des Enzymstandards zuzuschreiben sind, konnte durch Einsatz von Standardlösung gleicher katalytischer Aktivität aus verschiedenen Fläschchen unter Verwendung der gleichen Substratlösung nachgewiesen werden. Hierbei ergaben sich gut reproduzierbare Trübungsminderungen. Es müssen vielmehr Unterschiede zwischen den einzelnen getrennt aufgelösten Substratemulsionen aus einer Charge vorliegen. Sie könnten auf der bereits erwähnten Schwierigkeit beruhen, das lyophilisierte Substanzgemisch auf ein definiertes Endvolumen zu bringen. Auch dürften andere Einflüsse, wie die Temperatur beim Rekonstituieren, der zeitliche Abstand zwischen Zugabe des dest. Wassers und Beginn des Umschwenkens und die Art sowie Intensität des Mischens eine Rolle spielen. Ohne Frage reichen die Angaben des Herstellers: „Inhalt einer Flasche Lipase-Reagenz durch Auffüllen mit dest. Wasser bis zur Marke (ca. $27 \mathrm{ml}$ ) lösen" nicht aus. Andererseits genügt es auch nicht, wie in der Vorschrift empfohlen, nur „für jede Packung einmal die Extinktion des Standards (Doppelbestimmung) zu ermitteln". Der oben mitgeteilte Bereich von 0,050 bis 0,083 - entsprechend einem Verhältnis 1:1,6 - läßt die Größe des möglichen Fehlers erkennen, der bei Umrechnung auf die nur einmal gemessene Trübungsänderung des Standards auftreten kann. Zur Vermeidung derartiger systematischer Fehler von Serie zu Serie führten wir nach jeder neuen Auflösung von Substrạt Standardwerte (Dreifachbestimmungen) mit. Der errechnete Mittelwert des Meßsignals diente zur Auswertung.

Wird der gelöste Standard gut verschlossen bei +2 bis $+8^{\circ} \mathrm{C}$ aufbewahrt und werden Verunreinigungen sowie Bakterienwachstum vermieden, so ist die katalytische Aktivität der Lipase selbst nach 5 Monaten noch unver= ändert erhalten.

\section{Reaktionsablauf}

Der Sollwert der in unseren Untersuchungen verwendeten Enzymstandards betrug 452 bzw. 479 U/1. Wird ein solcher Standard in den sogenannten turbidimetrischen Test eingesetzt, so beobachtet man etwa zwischen der 2. und 15. Minute nach Start einen geradlinigen Reäktionsablauf (Tab. 1).

Im Gegensatz dazu verhalten sich die.Rroben ganz unterschiedlich. Bei der überwiegenden Zahl der untersuchten Seren nahm die Trübung während der empfohlenen Meßzeit zwischen 4 und 9 Minuten linear ab (Tab. 1). Ein Teil der übrigen Proben zeigte êrst żu einem späteren Zeitpunkt einen geradlinigen Absorptionsabfall, ein anderer Teil ergab ein konstantes Meßsignal oder ließ anfangs eine Zunahme, später eine Abnahme der Trübung erkennen (Tab. 2). Diese Irregularitäten im Verlauf der Meßreaktion variieren nicht nur von Probe zu Probe, sondern auch bei Einsatz verschiedener Verdünnungen der gleichen Probe (Abb. 1, Tab. 3). Dabei zeigte sich eine gewisse Systematik: Je weniger Serum der Testansatz enthielt, desto länger dauerte die Phase der Trübungszunahme und desto später setzte eine konstante „Extinktionsabnahme" ein.

Tab. 1. Beispiele für geradlinigen Reaktionsablauf im sogenannten turbidimetrischen Test $\left(, \Delta A^{\prime \prime} 365 \mathrm{~nm} / \mathrm{min}\right)$.

\begin{tabular}{|c|c|c|c|c|}
\hline $\begin{array}{l}\text { Zeit } \\
\text { nach } \\
\text { Start } \\
(\mathrm{mm})\end{array}$ & $\begin{array}{l}\text { Enzym- } \\
\text { standard } \\
452 \mathrm{U} / 1\end{array}$ & Serum 89 & Serum 43 & Serum 4 \\
\hline $\begin{array}{r}2 \\
3 \\
4 \\
5 \\
6 \\
7 \\
8 \\
9 \\
10 \\
11 \\
12 \\
13 \\
14 \\
15\end{array}$ & $\begin{array}{l}-0,012 \\
-0,013 \\
-0,013 \\
-0,012 \\
-0,012 \\
-0,013 \\
-0,012 \\
-0,011 \\
-0,011 \\
-0,012 \\
-0,011 \\
-0,011 \\
-0,012 \\
-0,012\end{array}$ & $\begin{array}{l}-0,023 \\
-0,025 \\
-0,025 \\
-0,025 \\
-0,025 \\
-0,025 \\
-0,025 \\
-0,024 \\
-0,024 \\
-0,024 \\
-0,023 \\
-0,023 \\
-0,023 \\
-0,022\end{array}$ & $\begin{array}{l}-0,003 \\
-0,004 \\
-0,004 \\
-0,003 \\
-0,005 \\
-0,004 \\
-0,004 \\
-0,004 \\
-0,004 \\
-0,004 \\
-0,005 \\
-0,005 \\
-0,005 \\
-0,005\end{array}$ & $\begin{array}{r}0,000 \\
-0,001 \\
-0,001 \\
-0,001 \\
-0,001 \\
-0,001 \\
-0,002 \\
-0,001 \\
-0,001 \\
-0,001 \\
-0,001 \\
-0,001 \\
-0,001 \\
-0,001\end{array}$ \\
\hline
\end{tabular}

- = „Extinktionsabfall“

Tab. 2. Beispiele für nicht geradlinigen Reaktionsablauf im sogenannten turbidimetrischen Test $\left(, \Delta A^{\prime \prime} 365 \mathrm{~nm} / \mathrm{min}\right)$.

\begin{tabular}{|c|c|c|c|c|c|c|}
\hline \multicolumn{2}{|c|}{$\begin{array}{l}\text { Zeit Serum } \\
\text { naçh } 197 \\
\text { Start } \\
\text { (min) }\end{array}$} & $\begin{array}{l}\text { Serum } \\
123\end{array}$ & $\begin{array}{l}\text { Serum } \\
49\end{array}$ & $\begin{array}{l}\text { Serum } \\
11\end{array}$ & $\begin{array}{l}\text { Serum } \\
28\end{array}$ & $\begin{array}{l}\text { Serum } \\
310\end{array}$ \\
\hline 2 & $-0,008$ & $-0,009$ & 0,000 & $+0,003$ & $+0,005$ & $+0,022$ \\
\hline 3 & $=0,009$ & $-0,013$ & 0,000 & $+0,001$ & $+0,004$ & $+0,015$ \\
\hline 4 & $-0,010$ & $-0,014$ & 0,000 & $+0,001$ & $+0,004$ & $+0,014$ \\
\hline 5 & $-0,010$ & $-0,015$ & 0,000 & $+0,001$ & $+0,003$ & $+0,011$ \\
\hline 6 & $-0,011$ & $-0,017$ & $-0,001$ & 0,000 & $+0,002$ & $+0,008$ \\
\hline 7 & $-0,012$ & $-0,018$ & 0,000 & 0,000 & $+0,001$ & $+0,007$ \\
\hline 8 & $-0,013$ & $-0,019$ & 0,000 & 0,000 & $+0,001$ & $+0,005$ \\
\hline 9 & $-0,013$ & $-0,019$ & 0,00 & $-0,0$ & 0,000 & $+0,006$ \\
\hline 10 & $-0,014$ & $-0,019$ & 0,000 & $-0,001$ & 0,000 & $+0,004$ \\
\hline 11 & $-0,014$ & $-0,020$ & 0,000 & $-0,001$ & 0,000 & $+0,004$ \\
\hline 12 & $-0,013$ & $-0,019$ & 0,000 & $-0,001$ & 0,000 & $+0,003$ \\
\hline 13 & $-0,013$ & $-0,019$ & 0,000 & $-0,001$ & 0,000 & $+0,002$ \\
\hline 14 & $-0,012$ & $-0,019$ & 0,000 & $-0,002$ & $-0,001$ & $+0,002$ \\
\hline 15 & $-0,013$ & $-0,019$ & 0,000 & $-0,002$ & $-0,001$ & $+0,001$ \\
\hline
\end{tabular}

$==$,Extinktionsabfall"

$+=$ "Extinktionsanstieg“

Abhängigkeit des Meßsignals von der eingesetzten Enzymmenge

Analysiert man Verdünnungen des Standards in physiologischer $\mathrm{NaCl}$-Lösung, so findet man bis zu $10 \%$ der Ausgangsaktivität einen geradlinigen $\mathrm{Zu}$ sammenhang zwischen der Enzymmenge im Test und der Trübungsabnahme pro Zeiteinheit (Abb. 2). 


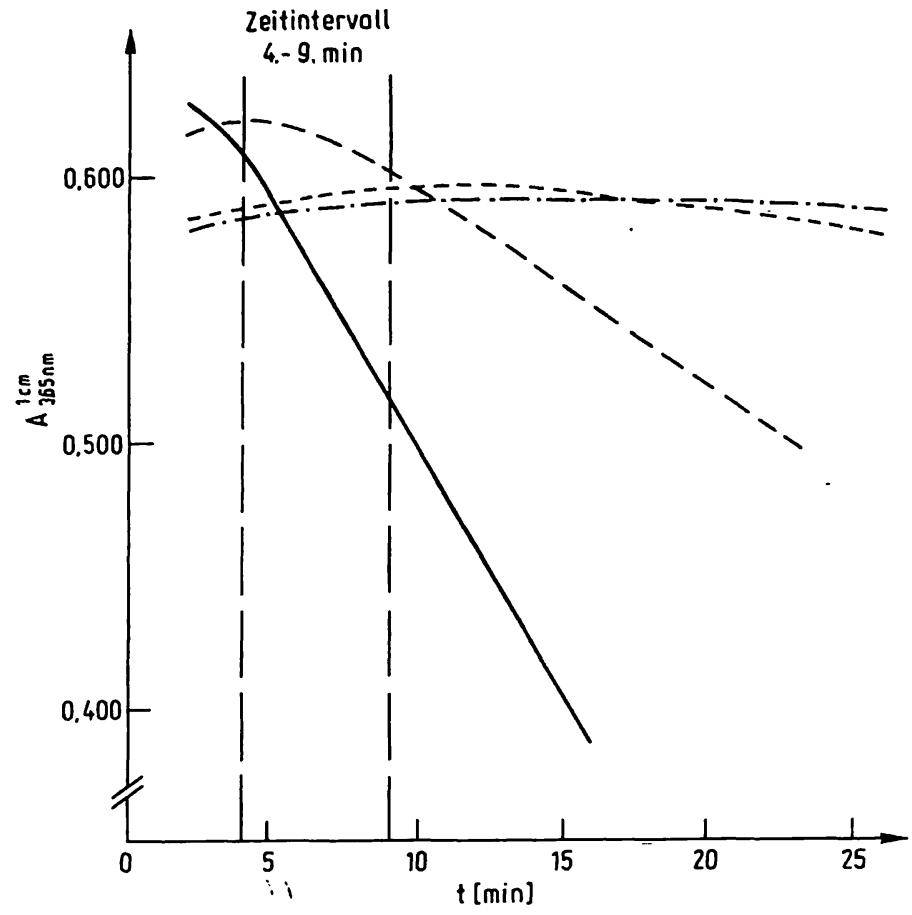

Abb. 1. Abhängigkeit des Reaktionsablaufs vom eingesetzten Probevolumen im sogenannten turbidimetrischen Test. Serum M., kataly tische Aktivität im titrimetrischen Test $=430 \mathrm{U} / 1$.

Katalytische Aktivitäten im sogenannten turbidimetrischen Test, jeweils aus dem geradlinigen Anteil des Reaktionsablaufs ermittelt (in Klammern: relative katalytische Aktivität bezogen auf die Aktivität bei Einsatz von $100 \mu 1$ Probe in den Test $=100$ ).

$\begin{array}{lrrr} & 100 \mu \mathrm{l} / \text { Test } & =710 \mathrm{U} / 1 & (100) \\ --- & 50 \mu \mathrm{l} / \text { Test } & =560 \mathrm{U} / 1 & (79) \\ -\cdots & 20 \mu \mathrm{T} / \text { Test } & =335 \mathrm{U} / 1 & (47) \\ -\cdot- & 10 \mu \mathrm{l} / \text { Test }= & =150 \mathrm{U} / 1 & (21)\end{array}$

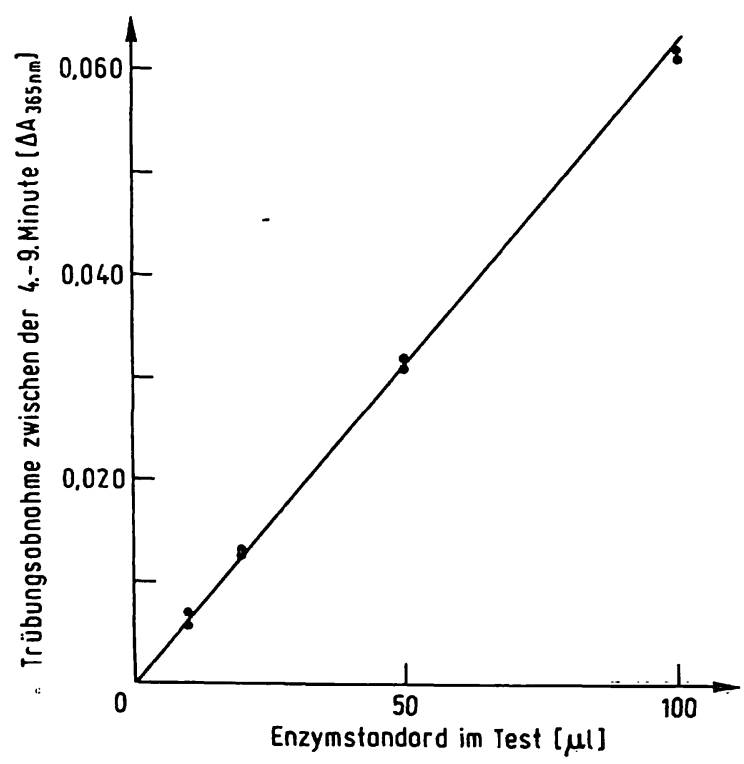

Abb. 2. Abhängigkeit des Meßsignals vom eingesetzten Volumen Enzymstandard im sogenannten turbidimetrischen Test. Die verwendete Verdünnung des Standards ist in $\mu \mathrm{l}$ unverdünntem Standard aufgetragen.
Tab. 3. Beispiel für nicht geradlinigen Reaktionsablauf im sogenannten turbidimetrischen Test bei Einsatz von Serumverdünnungen $\left(, \Delta \mathrm{A}^{“} 365 \mathrm{\textrm {nm }} / \mathrm{min}\right)$.

\begin{tabular}{|c|c|c|c|c|c|}
\hline \multirow{2}{*}{$\begin{array}{l}\text { Zeit } \\
\text { nach } \\
\text { Start } \\
\text { (min) } \\
\end{array}$} & \multicolumn{5}{|c|}{ Serum M., Verdünnungen entsprechend $\mu \mathrm{l}$ Serum/Test } \\
\hline & $100 \mu \mathrm{l}$ & $80 \mu l$ & $50 \mu \mathrm{l}$ & $29 \mu l$ & $10 \mu 1$ \\
\hline $\begin{array}{r}2 \\
3 \\
4 \\
5 \\
6 \\
7 \\
8 \\
9 \\
10 \\
11 \\
12 \\
13 \\
14 \\
15 \\
16 \\
17 \\
18 \\
19 \\
20 \\
21 \\
22 \\
23 \\
24 \\
25\end{array}$ & $\begin{array}{l}-0,010 \\
-0,013 \\
-0,015 \\
-0,016 \\
-0,017 \\
-0,019 \\
-0,019 \\
-0,019 \\
-0,020 \\
-0,018 \\
-0,020 \\
-0,019 \\
-0,019 \\
-0,019 \\
-0,019 \\
-0,018 \\
-0,017 \\
-0,018 \\
-0,017 \\
-0,018 \\
-0,016 \\
-0,016 \\
-0,016 \\
-0,016\end{array}$ & $\begin{array}{l}-0,003 \\
-0,007 \\
-0,008 \\
-0,010 \\
-0,012 \\
-0,012 \\
-0,011 \\
-0,012 \\
-0,013 \\
-0,013 \\
-0,014 \\
-0,012 \\
-0,014 \\
-0,012 \\
-0,013 \\
-0,013 \\
-0,012 \\
-0,013 \\
-0,012 \\
-0,012 \\
-0,012 \\
-0,011 \\
-0,012 \\
-0,011\end{array}$ & $\begin{array}{l}+0,003 \\
+0,002 \\
-0,001 \\
-0,003 \\
-0,004 \\
-0,005 \\
-0,006 \\
-0,007 \\
-0,007 \\
-0,007 \\
-0,007 \\
-0,007 \\
-0,008 \\
-0,008 \\
-0,008 \\
-0,007 \\
-0,007 \\
-0,008 \\
-0,007 \\
-0,008 \\
-0,007 \\
-0,007 \\
-0,006 \\
-0,007\end{array}$ & $\begin{array}{r}+0,002 \\
+0,002 \\
+0,002 \\
+0,001 \\
+0,001 \\
-0,002 \\
0,000 \\
+0,001 \\
0,000 \\
0,000 \\
-0,001 \\
0,000 \\
-0,001 \\
-0,001 \\
-0,001 \\
-0,001 \\
-0,001 \\
-0,002 \\
-0,001 \\
=0,001 \\
-0,002 \\
-0,002 \\
-0,002 \\
-0,002\end{array}$ & $\begin{array}{r}+0,003 \\
+0,002 \\
+0,001 \\
+0,001 \\
+0,001 \\
0,000 \\
-0,001 \\
+0,001 \\
0,000 \\
0,000 \\
0,000 \\
0,000 \\
-0,001 \\
0,000 \\
0,000 \\
0,000 \\
0,000 \\
-0,001 \\
0,000 \\
0 ; 000 \\
-0 ; 001 \\
=0,001 \\
0,000 \\
=0,001\end{array}$ \\
\hline
\end{tabular}

$-=$,Extinktionsabfall"“

$+=$ „Extinktionsanstieg“

Die Serumproben dagegen zeigen auch in diéser Hinsicht ein ganz unterschiedliches Verhalten:

Von den 16 in Verdünnungsreihen geprüften Seren ergaben zwei eine direkte Proportionalität zwischen Meßsignal und Probevolumen bei Auswertung nach Vorschrift (zwischen der 4. und der 9. Minute nach Start der Reaktion) (Tab. 4). Bei der höchsten Verdünnung ist zu berücksichtigen, daß die Meßsignale bei Einsatz von $10 \%$ Serum außerordentlich gering sind und auch die Abweichungen in der Anzeige mit dem Faktor 10 multipliziert werden. Bei beiden erwähnten

Tab. 4. Beispiele für geradlinigen Zusammenhang $z w i s c h e n$ Serumverdünnung und Meßsignal im sogènannten turbidimetrischen Test.

\begin{tabular}{|c|c|c|c|c|c|c|c|}
\hline \multirow[t]{2}{*}{$\begin{array}{l}\text { Serum } \\
\text { vom }\end{array}$} & \multirow{2}{*}{$\begin{array}{l}\text { Titrime- } \\
\text { trischer } \\
\text { Test } \\
\text { (U/1) }\end{array}$} & \multicolumn{6}{|c|}{ 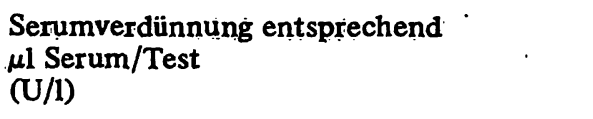 } \\
\hline & & $100 \mu \mathrm{l}$ & $80 \mu \mathrm{l}$ & $50 \mu 1$ & $40 \mu 1$ & $20 \mu l$ & $10 \mu \mathrm{ll}$ \\
\hline $\begin{array}{l}\text { R., } \\
22.3 .68\end{array}$ & & & $\begin{array}{l}1530 \\
1550\end{array}$ & $\begin{array}{l}1440 \\
1440\end{array}$ & $\begin{array}{l}1520 \\
1540\end{array}$ & $\begin{array}{l}1500 \\
1500\end{array}$ & $\begin{array}{l}1250 \\
1250\end{array}$ \\
\hline $\begin{array}{l}\text { H., } \\
27.1 .68\end{array}$ & $\bar{x} 1300$ & $\begin{array}{l}1200 \\
1200\end{array}$ & $\begin{array}{l}1170 \\
1170\end{array}$ & $\begin{array}{l}1.200 \\
1210\end{array}$ & $\begin{array}{l}1100^{\prime \prime} \\
1160\end{array}$ & $\begin{array}{l}1170 \\
1150\end{array}$ & $\begin{array}{l}1110 \\
1050\end{array}$ \\
\hline
\end{tabular}

Ausgewiwertet wurde der linẹare Trựbungsạball zwischen der 4. und 9. Minute nach Start. Die katalytischen Aktivitäten sind auf unverdünntes Serum̄an
umgerechnet. 
Proben zeigte sich auch eine befriedigende Ubereinstimmung der Ergebnisse mit dem titrimetrischen Test. Wurde bei Einsatz sehr hoher katalytischer Aktivitäten an Lipase - abweichend von der Vorschrift - der lineare Teil der registrierten Anfangsgeschwindigkeit ausgewertet, so ergab sich bei 4 Seren ein geradliniger $\mathrm{Zu}$ sammenhang zwischen Serumvolumen im Test und initialer Trübungsabnahme (Tab. 5). Bei diesen stark erhöhten Werten wurden allerdings die.Ergebnisse der kontinuierlichen Titration nicht erreicht.

Tab. 5. Zusammenhang zwischen Serumverdünnung und Meßsignal im sogenannten turbidimetrischen Test bei Einsatz von stark erhöhten katalytischen Aktivitäten an Lipase.

\begin{tabular}{lllllllll}
\hline $\begin{array}{l}\text { Serum } \\
\text { vom }\end{array}$ & $\begin{array}{l}\text { Titrime- } \\
\text { trischer } \\
\text { Test } \\
(\mathrm{U} / \mathrm{l})\end{array}$ & $\begin{array}{l}\text { Serumverdünnung entsprechend } \\
\mu 1 \text { Serum/Test } \\
(\mathrm{U} / \mathrm{l})\end{array}$ \\
& $100 \mu \mathrm{l}$ & $80 \mu \mathrm{l}$ & $50 \mu \mathrm{l}$ & $40 \mu \mathrm{l}$ & $20 \mu \mathrm{l}$ & $10 \mu \mathrm{l}$ \\
\hline B., & $\overline{\mathrm{x}} 2800$ & 2480 & 2400 & 2600 & 2480 & 2600 & 2380 \\
23.4 .68 & & 2450 & 2400 & 2580 & 2550 & 2500 & 2600 \\
C., & $\overline{\mathrm{x}} 5800$ & 3700 & 3620 & 4000 & 4250 & 4050 & 4000 \\
21.10 .69 & & 3850 & 3700 & 4000 & 4250 & 4180 & 4000 \\
Sch., & $\overline{\mathrm{x}} 11000$ & 8000 & 7500 & 8600 & 8500 & 8000 & 7550 \\
14.8 .69 & & 7850 & 7500 & 8500 & 8650 & 7900 & 7550 \\
M., & $\overline{\mathrm{x}} 6000$ & 4820 & 4880 & 5230 & 5050 & 4530 & 4380 \\
4.6 .69 & & 4820 & 4950 & 5200 & 4460 & 4500 & 4170 \\
\hline
\end{tabular}

Auswertung - abweichend von der Vorschrift - über die Anfangsgeschwindigkeit.

Die katalytischen Aktivitäten sind auf unverdünntes Serum urngerechnet.

Bei den übrigen 10 Seren diente der geradlinige Reaktionsablauf - unabhängig vom Zeitpunkt seines Auftretens - zur Berechnung. Vor allem bei hohen Verdünnungen wurde erșt nach etwa 20 Minuten eine Linearität beobachtet; in einem Fall kam es sogar zu einer Trübungszunahme. Die hohen katalytischen Aktivitäten machten wiederum eine Auswertung der Anfangsgeschwindigkeit erforderlich. Bei einer derartig modi: fizierten Berechnung zeigten sich um so höhere katalytische Aktivitäten an Lipase, je mehr Serum in dèn -Test eingesetzt wurde (Tab. 6). Da es keine logische Grundlage für die Auswahl eines Ergebnisses aus den unterschiedlichen Daten einer Verdünnungsreihe gibt, ist die Berechnung einer Korrelation mit den Resultaten des titrimetrischen Tests nicht möglich.

Zur Verdeutlichung ist in den Abbildungen 1 und 3 der Reaktionsablauf von zwei Seren aus Tabelle 6 graphisch dargestellt. Die in Abbildung 1 gezeigte Probe ergab während der Zeit zwischen der 4. und 9. Minute keine geradlinige Signaländerung, daher wurde jeweils der lineare Teil der Kurven zur Auswertung herangezogen.
Mit $100 \mu \mathrm{l}$ Serum fand sich eine wesentlich höhere katalytische Aktivität als beim kontinuierlichen titrimetrischen Verfahren, geringere Serummengen führten zu fälschlich emiedrigten kataly tischen Aktivitäten. Ein ganz anderres Verhalten zeigt Abbildung 3: Mit $100 \mu \mathrm{l}$ Serum wurde ein geradliniger Abfall der Trübung während der vorgeschriebenen Meßzeit beobachtet; auch 50 und $20 \mu \mathrm{l}$ Probe im Test ergaben einen geradlinigen Verlauf, jedoch ein zu geringes , $\Delta \mathrm{A}$ “; es entsprach $80 \%$ bzw. $46 \%$ des Ausgangswertes. Bei Einsatz von $10 \mu \mathrm{l}$ Probe fand sich sogar eine Trübungszunahme.

Die in Tabelle 6 zuerst aufgefuhrten 8 Seren wurden am Tage der Entnahme untersucht. Die restlichen Ergebnisse sind an Proben gewonnen worden, die seit 1967, 1968 bzw. 1969 bei $-20^{\circ} \mathrm{C}$ konserviert waren. Beim Vergleich der Resultate an frischen und eingefrorenen Seren zeigte sich auffalligerweise bei dem tiefgefrorenen Material eine bessere Korrelation zwischen eingesetzter Probenmenge und gemessener Trübungsabnahme. Dies steht im Widerspruch zu der zunächst vom Reagentien-Hersteller gemachten Angabe, daß eingefrorene Seren nicht im turbidimetrischen Test analysiert werden könnten.

Tab. 6. Beispiele für nicht geradlinigen Zusammenhang zwischen Serumverdünnung und Meßsignal im sogenannten turbidimetrischen Test.

\begin{tabular}{|c|c|c|c|c|c|c|c|}
\hline \multirow[t]{2}{*}{$\begin{array}{l}\text { Serum } \\
\text { vom }\end{array}$} & \multirow{2}{*}{$\begin{array}{l}\text { Titrime= } \\
\text { trischer } \\
\text { Test } \\
\text { (U/l) }\end{array}$} & \multicolumn{6}{|c|}{$\begin{array}{l}\text { Serumverdünnung entsprechend } \\
\text { l Serum/Test } \\
(\mathrm{U} / \mathrm{l})\end{array}$} \\
\hline & & $100 \mu 1$ & $80 \mu \mathrm{l}$ & $50 \mu \mathrm{l}$ & $40 \mu l$ & $20 \mu \mathrm{l}$ & $10 \mu \mathrm{l}$ \\
\hline $\begin{array}{l}29 \\
6.5 .80\end{array}$ & $\overline{\mathbf{x}} 720$ & $\begin{array}{l}1260 * \\
1240\end{array}$ & & $\begin{array}{l}508^{*} \\
592\end{array}$ & & $\begin{array}{l}430 * \\
530\end{array}$ & $\begin{array}{l}140^{*} \\
210\end{array}$ \\
\hline $\begin{array}{l}\text { H., } \\
30.4 .80\end{array}$ & $\bar{x} 1600$ & $\begin{array}{l}2030 * * \\
2020\end{array}$ & & $\begin{array}{l}2060 \\
2100\end{array}$ & & $\begin{array}{l}1770 \\
1840\end{array}$ & $\begin{array}{l}1270 \\
1340\end{array}$ \\
\hline $\begin{array}{l}\text { N., } \\
19.5 .80\end{array}$ & $\bar{x} 430$ & & $\begin{array}{l}603 * \\
612\end{array}$ & $\begin{array}{l}564 * \\
550\end{array}$ & $\begin{array}{l}462 * \\
462\end{array}$ & $\begin{array}{l}335^{*} \\
335\end{array}$ & $\begin{array}{l}150^{*} \\
150\end{array}$ \\
\hline $\begin{array}{l}\text { M., } \\
21.5 .80\end{array}$ & $\bar{x} 630$ & $\begin{array}{l}770 \\
770\end{array}$ & $\begin{array}{l}678 \\
695\end{array}$ & $\begin{array}{l}608^{*} \\
624\end{array}$ & $\begin{array}{l}593^{*} \\
593\end{array}$ & $\begin{array}{l}480^{*} \\
520\end{array}$ & $\begin{array}{l}220^{*} \\
210\end{array}$ \\
\hline $\begin{array}{l}\text { Mo., } \\
22.5 .80\end{array}$ & $\bar{x} 590$ & & $\begin{array}{l}659 * \\
659\end{array}$ & $\begin{array}{l}668^{*} \\
628\end{array}$ & $\begin{array}{l}520^{*} \\
555\end{array}$ & $\begin{array}{l}555^{*} \\
480\end{array}$ & $\begin{array}{l}300 * \\
300\end{array}$ \\
\hline $\begin{array}{l}\text { C., } \\
20.5 .80\end{array}$ & $\bar{x} 670$ & $\begin{array}{l}926 \\
926\end{array}$ & $\begin{array}{l}853 \\
833\end{array}$ & $\begin{array}{l}830 \\
800\end{array}$ & $\begin{array}{l}722 \\
744\end{array}$ & $\begin{array}{l}670 \\
705\end{array}$ & $\begin{array}{l}520 \\
520\end{array}$ \\
\hline $\begin{array}{l}\text { Mi., } \\
\text { 26.5.80 }\end{array}$ & $\overline{\mathrm{x}} 420$ & & $\begin{array}{l}491 \\
491\end{array}$ & $\begin{array}{l}460 \\
474\end{array}$ & $\begin{array}{l}462 \\
427\end{array}$ & $\begin{array}{l}410 \\
400\end{array}$ & $\begin{array}{l}220 \\
200\end{array}$ \\
\hline $\begin{array}{l}\text { P., } \\
28.5 .80\end{array}$ & $\overline{\mathbf{x}} 650$ & $\begin{array}{l}577 \\
594\end{array}$ & $\begin{array}{l}510 \\
521\end{array}$ & $\begin{array}{l}460 \\
480\end{array}$ & $\begin{array}{l}400 \\
443\end{array}$ & $\begin{array}{l}265 \\
220\end{array}$ & 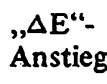 \\
\hline $\begin{array}{l}\text { R., } \\
10.6 .67\end{array}$ & $\overline{\mathbf{x}} 1600$ & $\begin{array}{l}1380 \\
1400\end{array}$ & $\begin{array}{l}1410 \\
1420\end{array}$ & $\begin{array}{l}1440 \\
1480\end{array}$ & $\begin{array}{l}1280 \\
1310\end{array}$ & $\begin{array}{l}1200 \\
1280\end{array}$ & $\begin{array}{l}1050 \\
1000\end{array}$ \\
\hline $\begin{array}{l}\text { T., } \\
14.7 .68\end{array}$ & $\bar{x} 1500$ & $\begin{array}{l}1370 \\
1340\end{array}$ & $\begin{array}{l}1390 \\
1400\end{array}$ & $\begin{array}{l}1410 \\
1420\end{array}$ & $\begin{array}{l}1290 \\
1310 .\end{array}$ & $\begin{array}{l}1200 \\
\cdot 1200\end{array}$ & $\begin{array}{r}1110 \\
970\end{array}$ \\
\hline
\end{tabular}

Auswertung nach Vorschrift zwischen der 4. und 9. Minute nach Start.

* Auswertung des linearen Trübungsabfalls zu einem späteren Zeitpunkt.

** Auswertung der Anfangsgeschwindigkeit.

Die katalytischen Aktivitäten sind auf unverdünntes Serum umgerechnet. 


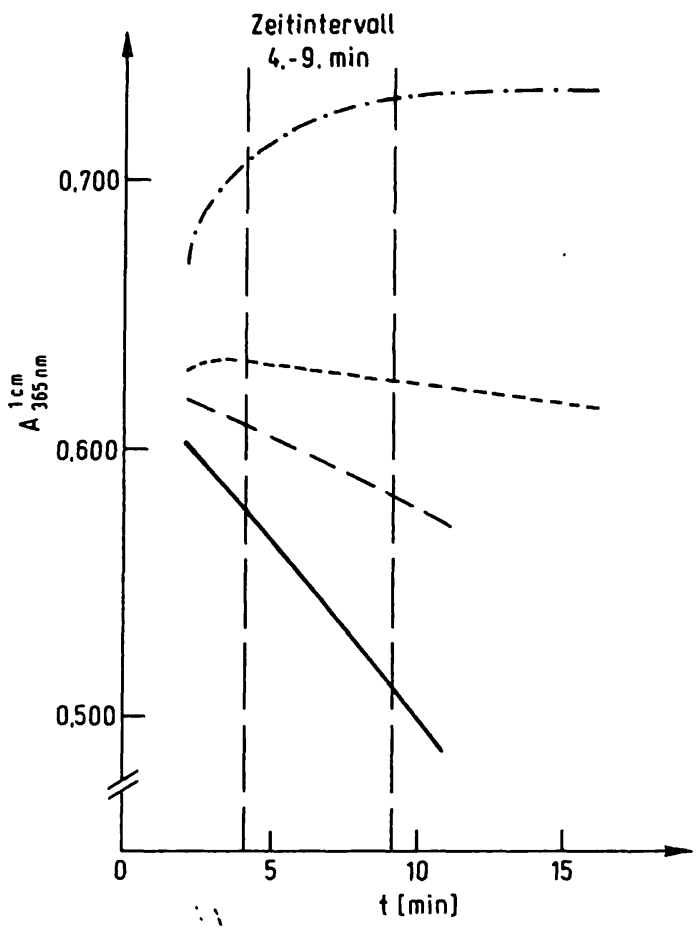

Abb. 3. Abhängigkeit des Reaktionsverlaufs vom eingesetzten Probevolumen im sogenannten turbidimetrischen Test. Serum P., kataly tische Aktivität im titrimetrischen Test $=650 \mathrm{U} / 1$.

Katalytische Aktivitäten im sogenannten turbidimetrischen Test, jeweils aus dem , $\Delta \mathrm{A}^{\prime \prime} \mathrm{zwischen}$ der 4. und 9. Minute nach Start der Reaktion ermittelt (in Klammern: relative kataly tische Aktivität bezogen auf die Aktivität bei Einsatz von $100 \mu \mathrm{l}$ Probe in den Test $=100$ )

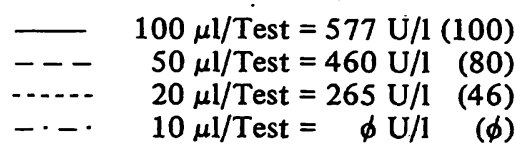

\section{Probleme durch Konstanz bzw. Zunahme der Trübung} im Testansatz

Wie bereits in den Tabellen 2 und 3 sowie den Abbildungen 1 und 3 gezeigt wurde, beobachtet man bei einem Teil der Seren bzw. Serumverdünnungen eine Konstanz bzw. Zunahme der Trübung anstelle der erwarteten „Extinktionsabnahme“. Unter den von uns analysierten 1238 Proben fanden sich 103, die dieses Verhalten zeigten und deren katalytische Aktivität an Lipase daher mit dem sogenannten turbidimetrischen Test nicht gemessen werden konnte. Beispiele aus einer Serie sind in Tabelle 7 zusammengestellt. In allen 7 Seren konnten im titrimetrischen Test katalytische Aktivitäten an Lipase bestimmt werden, die im Normbereich lagen. Zwei Seren wurden 24 Stunden später erneut analysiert; die Zunahme der Trübung w̄ar wesentlich stärker ausgeprägt. Dieser Effekt wurde auch in späteren Serien gefunden, jedoch von uns nicht systematisch untersucht.

Die Ursache der beschriebenen Störung ist bisher nicht bekannt. Wahrscheinlich beruht sie darauf, daß zwei
Reaktionen von unterschiedlicher Auswirkung auf das Meßsignal gleichzeitig ablaufen: Die durch die katalytische Aktivität der Lipase bedingte Trübungsabnahme und eine sich überlagernde serumspezifische Trübungszunahme. Die Trübungsżunahme könnte möglicherweise durch einen Proben-Leerwert ohne Tridlein kompensiert werden (Prellwitz (4)). Untersuchungen hierzu erwiesen sich jedoch als nicht durchführbạr, da die Zusammensetzung des im Handel befindlichen Substrats nicht vollständig deklariert ist (s.o.) und wir daher das LeerwertReagens nicht selbst ansetzen konnten. Dem Vorschlag, uns ein solches Leerwert-Reàgens ohne Sübstrat zur Verfugung zu stellen, ist der Hersteller bisher leider nicht gefolgt.

Tab. 7. Beispiele für Seren, die im sogenanñnten turbidimetrischen Test eine Trübungszunahme bzw. eine Konstanz des Meßsignals zeigten.

\begin{tabular}{|c|c|c|}
\hline \multirow[t]{2}{*}{$\begin{array}{l}\text { Titrimetrischer } \\
\text { Test } \\
\text { (U/1) }\end{array}$} & \multicolumn{2}{|c|}{$\begin{array}{l}\text { Turbidimetrischer Test } \\
\text { Änderung der ,Extinktion “" } \\
\text { zwischen 4. und 9. Minute }\end{array}$} \\
\hline & frisches Serum & $\begin{array}{l}\text { gleiches Serum } \\
\text { nach } 24 \mathrm{~h}+4^{\circ} \mathrm{C}\end{array}$ \\
\hline $\begin{array}{l}49 \\
39 \\
78 \\
65 \\
93 \\
17 \\
67\end{array}$ & $\begin{array}{r}+0,001 \\
+0,010 \\
+0,004 \\
+0,015 \\
0,000 \\
+0,024 \\
+0,013\end{array}$ & $\begin{array}{l}+0,045 \\
+0,031\end{array}$ \\
\hline
\end{tabular}

$+=$,Extinktionszunahme“

Kataly tische Aktiv̄ität im titrimetrischen Test = Mittelwert aus Doppel- bzw. Dreifachbestimmungen.

\section{Meßtechnische Empfindlichkeit des sogenännten turbi- dimetrischen Tests}

Der verwendete Lipasestandard mit einer katalytischen Konzentration von 452 U/1 ergab nach unseren Messungen bei $365 \mathrm{~nm}$ eine Trübungsabnahme, die eiñem „, $\Delta A$ " von größenordnungsimmäßig 0,060 in 5 Minuten oder 0,012 pro-Minute entsprach. Somit findet sich bei katalytischen Aktivitäten an der oberen Grenze des Referenzbereichs (140 U/1) nur eine Änderung dès Meßsignalš von etw̌̀a $0,004 / \mathrm{min}$ und bèi èiner katalytischen Aktivität an Lipase von $35 \mathrm{U} / 1$ entspre.

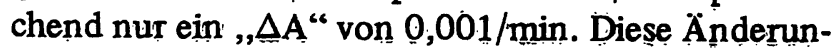
gen sind viel geringer als z.B. die Absorptionsdifferenzen im UV-Test zur Bestimmung der Transaminasen, bei denen die Präzision an der Grenze des Referenzbereichs auch schon nicht żufriēenstellènd ist. Die Messung der Lipase bei $334 \mathrm{~nm}$ ergibt keine wesentliche Steigerung der Empfindlichkeit, da die Meßsignale nur um $15 \%$ höher liegen als bei $365 \mathrm{~nm}$, andererseits aber die Stabilität der Anzeige geringer ist. Berücksichtigt man weiterhin, daß die anfängliche Trübung - gegen dest. Wasser gemessen - einer Absorption von mehr 
als 1,000 entspricht, so werden die meßtechnischen Schwierigkeiten und die allein hierdurch möglichen Fehler deutlich.

\section{Spezifität}

Im titrimetrischen Test mit Triolein als Substrat und in Anwesenheit optimaler Na-Glykocholat-Konzentrationen wird die katalytische Aktivität der Lipoproteinlipase mitgemessen, deren Höhe 10-30 min nach Heparininjektion etwa $200-400 \mathrm{U} / 1$ beträgt (5). Im sogenannten türbidimetrischen Test liegt die Gallensalzkonzentration mit $19 \mathrm{mmol} / 1$ so hoch, daß die Lipoproteinlipase weitgehend gehemmt ist. Die Hemmung der Pankreaslipase unter diesen Testbedingungen wird durch den Zusatz von Colipase aufgehoben. Bei Einsatz von gereinigter Pankreaslipase aus menschlichem Duodenalsaft fanden wir im sogenannten turbidimetrischen Test nur 7\% der mit dem titrimetrischen Verfahren gemessenen Aktivität. Die Ursache dieser Diskrepanz ist unklar.

\section{Vergleichsuntersuchungen}

Um die diagnostische Zuverlässigkeit des sogenannten turbidimetrischen Tests zu prüfen, führten wir an 107 Seren Vergleichsuntersuchungen mit dem titrimetrischen Verfahren als Referenzmethode aus. Keiner der Patienten hatte Heparin erhalten. In jeder Serie wurden Kontrollproben analysiert; bei der Titrimetrie betrug der Variationskoeffizient (VK) von Tag zu Tag 2,5\% ( $n=25)$, beim sogenannten turbidimetrischen Test 3,4\% $(n=13)$.

Unter den bei der sogenannten Turbidimetrie ermittelten Meßdaten fanden sich 9, die nicht ausgewertet werden konnten: Ein Serum zeigte keine Trübungșändeñung, bei 6 Proben ergab sich eine Zunahme der Trübung. Die katalytischen Aktivitäten diesèr Seren an Lipase betrugen mit der Referenzmethode $49,39,78,65,93,17$ und 67 U/1 (Täb. 7). Bei weiteren zwei Seren mit stark erhöhten katalytischen Aktivitäten ergạben sich die bereits besprochenen Probleme hinsichtlich der Auswertung bei Einsatz von Serumverdünnungen in phyiologischer $\mathrm{NaCl}-\mathrm{L}$, ösung. Die übrigen 98 Datenpaare wurden mit dem Wilcoxon-Test auf Ubereinstimmung geprüft; die Ergebnisse beider Methoden weichen signifikant voneinandèr $\mathrm{ab}(\mathrm{P}<0,0001)$.

Die Ergebnisse von 80 Seren mit katalytischen Aktivitäten von bis zu $150 \mathrm{U} / \mathrm{l}$ bei der Titration sind in Abbildung 4 dargestellt. Die einzelnen Punkte entsprechen Mittelwerten aus Doppel- bis Vierfachbestimmungen. Es zeigt sich eine Punktwolke mit erheblichen Abweichungen in beiden Richtungen. Wird trotzdem die Korrelation berechnet, so ergibt sich ein Korrelationskoeffizient von $r=0,87$. Die Gleichung der Regressionsgeraden lautet: $y=-10+0,98 x$. Abbildung 5 zeigt Daten von 18 Seren mit erhöhter Lipase. Obwohl der sogenannte turbidimetrische Test in diesem Bereich aufgrund des höheren Meßsignals besser ausgewertet werden kann, ist die Korrelation mit $r=0,86$ nicht enger als bei Normalseren. Auch hier ergibt die Gleichung der Regressionsgeraden $(y=48,6+0,73 x)$ einen erheblichen Ordinatenabschnitt. Da der Korrelationskoeffizient im Einzelfall nichts über die Vergleichbarkeit zweier Datenpaare aussagt, sind in Tabelle 8 die an 6 Seren gewonnenen Ergebnisse zusammengestellt, die erhebliche Abweichungen - insbesondere über die Grenze des Referenzbereichs hinaus - zeigten.

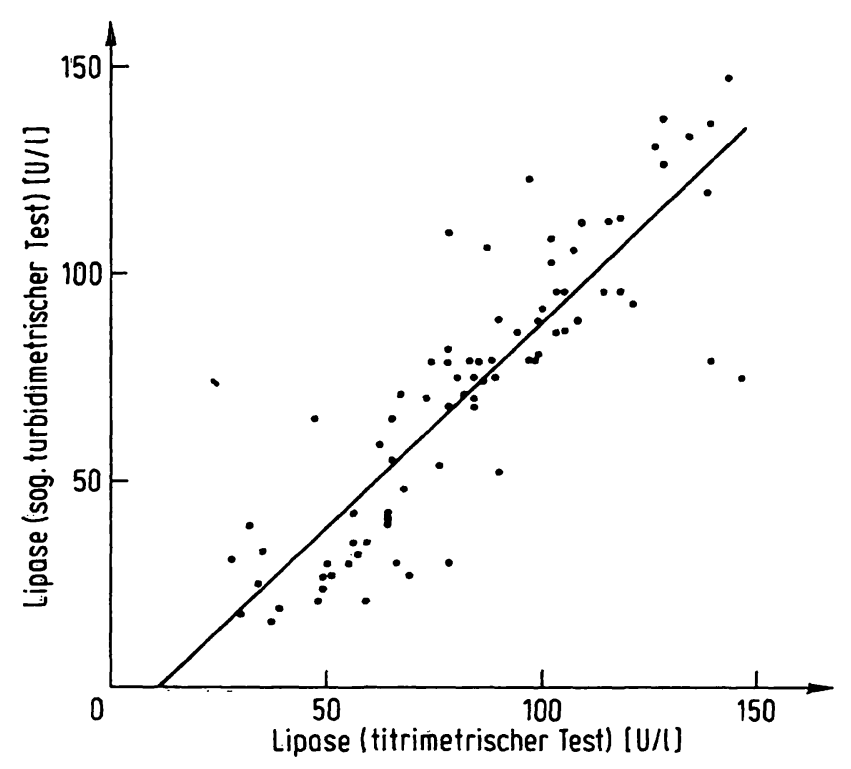

Abb. 4. Vergleichșuntersuchungen des sogenannten turbidimetrischen Tests mit dem titrimetrischen Verfahren an 80 Seren mit einer katalytischen Aktivität an Lipase bis zu $150 \mathrm{U} / \mathrm{l}$.

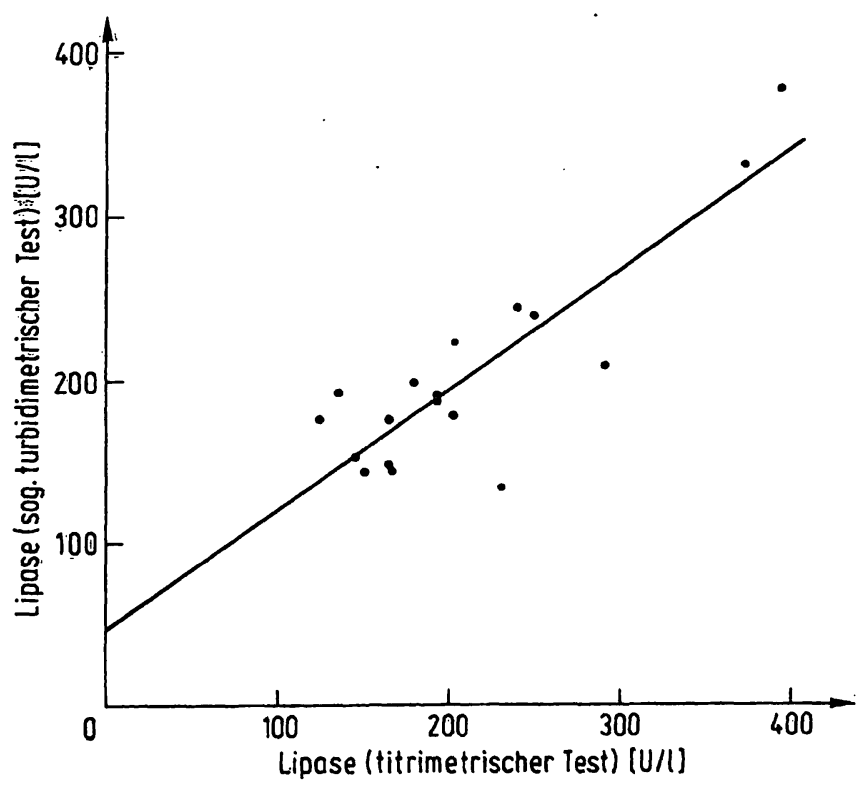

Abb. 5. Vergleichsuntersuchungen des sogenannten turbidimetrischen Tests mit dem titrimetrischen Verfahren an 18 Seren mit erhöhter katalytischer Aktivität an Lipase. 
Tab. 8. Beispiele für erhebliche Abweichungen zwischen den Ergebnissen des titrimetrischen und des sogenannten turbidimetrischen Tests.

\begin{tabular}{lll}
\hline Serum-Nr. & $\begin{array}{l}\text { Titrimetrischer } \\
\text { Test } \\
(\mathrm{U} / \mathrm{l})\end{array}$ & $\begin{array}{l}\text { Sogenannter turbi- } \\
\text { dimetrischer Test } \\
(\mathrm{U} / \mathrm{l})\end{array}$ \\
\hline 25 & 123 & 177 \\
27 & 146 & 75 \\
35 & 290 & 209 \\
50 & 139 & 79 \\
77 & 135 & 192 \\
94 & 230 & 134 \\
\hline
\end{tabular}

\section{Diskussion}

Von mehreren Autoren wurden Verfahren zur Bestimmung der Lipase im Serum beschrieben, bei denen die Abnahme der Trübung einer Triolein- bzw. OlivenölEmulsion mit Hilfe eines Photometers (sogenannte „Turbidimetrie") (Vogel \& Zieve 1963 (6), Shihabi \& Bishop 1971 (7), Verduin et al. 1973 (8), Ramiz et al. 1974 (9), Kreutzer et al. 1975 (10), Kok et al. 1978 (11) oder eines Nephelometers (Zinterhofer et al. 1973 (12)) gemessen wird. Hierbei bestehen einmal meßtechnische Schwierigkeiten; es ergeben sich vor allem Unterschiede der Ergebnisse in Abhängigkeit von der Art des verwendeten Photometers. Zum anderen ist das Problem der Auswertung der Meßsignale nicht einheitlich gelöst: Shihabi \& Bishop (7) nehmen irrtümlich an, daß eine vollständige Klärung der TriglyceridEmulsion bereits bei Abspaltung einer einzigen Fettsäure aus dem Triglyceridmolekül vorliegt. Bei Verduin et al. (8) erfolgt die Berechnung unter Bezugnahme auf eine einzige Probe, deren kataly tische Aktivität durch die Bestimmung der Kupfersalze freigesetzter Fettsäuren ermittelt wurde. Die Ergebnisse aller genannten Verfahren sind außerordentlich schlecht reproduzierbar, eine Standardisierung war bisher nicht möglich.

Der von Ziegenhorn et al. (1) entwickelte Test unterscheidet sich von den zuvor genannten vor allem durch den Zusatz von Colipase und durch die Auswertung über einen Enzymstandard, dessen katalytische Aktivität im titrimetrischen Verfahren ermittelt wurde. Durch die Berechnung über einen Standard sollen die Unterschiede bei Verwendung verschiedener Meßgeräte eliminiert werden. Der Reaktionsablauf dieser Modifikation zeigt bei Einsatz von reiner Lipase - ähnlich wie die anderen sogenannten turbidimetrischen Verfahren - anfangs eine lag-Phase, anschließend einen linearen Verlauf und schließlich eine Abnahme der Trübungsäñderung pro Minute als Zeichen dafür, daß die Reaktionsgeschwindigkeit durch Verminderung der Substratkonzentration abnimmt.

Ein ähnliches Verhalten wurde bei der Verwendung von Trilinolein als Substrat (13) beobachtet (14). Beim Ver- fahren nach Ziegenhorn et al. kann der oben beschriebene Reaktionsablauf, der durch die katalytische Aktivität der Lipase bedingt ist, bei Einsatz von Seren durch eine von Probe zu Probe stark unterschiedliche Trübungszunahme überlagert werden. Ähnliche Beobachtungen wurden bereits bei den früher beschriebenen sbgenannten turbidimetrischen bzw. nephelometrischen Verfahren mitgeteilt $(8,11,15,16,16 a)$. Als Ursache dieser Störung, die die Messung der katalytischen Aktivität der Lipase im sogenannten turbidimetrischen Test nach Vorschrift des Herstellers bei etwa $8 \%$ der hier untersuchten Seren und nach einer Mitteilung von Lorentz und Flatter (17) sogar bei mehr als $20 \%$ von 53 gemessenen Proben unmöglich machte, ist vor allem eine Veränderung von Serumbestandteilen zu diskutieren; etwa durch Anwwesenheit der relativ hohen Konzentration an Harnstoff (etwa $110 \mathrm{mmol} / \mathrm{l})$, Polyethylenglykol u.ä. Substanzen im Test. Kreutzer et al. (10) machen die hohe Konzentration an Na-desoxycholat dafür verantwortlich. Die. Frage, ob die Störungen durch einen Proben-Leerwient auszuschalten sind, konnte nicht geprüft werden, da uns ein LeerwertReagens ohne Substrat nicht zur Verfugung gestellt wurde und da es infolge unvollständiger Deklarierung der Testlösung nicht selbst angesetzt werden konnte. Auffällig ist, daß bei der Untersuchung von Standardlösungen und vorn Kontrollproben auf Albumininbasis eine Störung durch Trübungszunahme nicht zu erkennen war.

Da jede Probe eine eigene Kinetik hat (s. Tâb. 2 und 3 sowie Abb. 1 und 3), führt eine Ablesung und Auswertung entsprechend der Vorschrift zu festen Żeiten im Einzelfall zu falschen bzw. unsinnigen Ergebnissen (negative katalytische Aktivitäten!). Durch Modifikation đer Reagens-Zusammensetzung und Untersuchungen an einer ausreichenden Zahl frisch gèwonnener Probèn, bei denen die Kinetik - wie auch bereits Kreutżer et al. zeigen konnten (10) - besonders unbefriedigend ist, sollte der Hersteller die beschriebene Problematik zu klären versuchen.

Wie im titrimetrischen Test gezeigt werden konntê, ist die Lipase im Serum bei +4 bis $+8{ }^{\circ} \mathrm{C}$ und bei Raumtemperatur (25 Tage lang geprüft) hervorragend haltbar. Auch der Enzymstandard zeigte im sogenannten turbidimetrischen Verfahren èine für Enżỳne ungewöhnlich gute Stabilität (s.o.). Nach Angabe des Herstellers sind jedoch nur Seren, die nicht länger als 5 Tage im Kühlschrank aufbewahrt wurden, für die Messung im sogenannten turbidimetrischen Test geeignet. Bei Raumtemperatur sollen die Proben nicht länger als 24 . Stunden verwendbar sein. Diese schlechte Haltbarkeit kann nicht auf den Eigenschaften des Enzyms beruhen. Es ist vielmehr zu diskutieren, ob die Ursache darin liegt, daß es bei manchen Seren nach Lagerung zu einer Trübungsżunahme im Test kommt (s. Tab. 7).

Eine weitere Schwierigkeit stellt die Messung stark erhöhter katalytischer Aktivitäten von Lipase dar. Als Verdünnungsgrenze gibt der Hersteller 700 U/1 an; bei höheren katalytischen Aktivitäten wird eimpfohlen, eine 
Serumverdünnung mit physiologischer $\mathrm{NaCl}$-Lösung im Volumenverhältnis $1+1 \mathrm{zu}$ analysieren. Somit erstreckt sich der mögliche Meßbereich bis 1400 U/1. Bei Patienten mit akuter Pankreatitis wurden jedoch von uns zum Zeitpunkt der Klinikaufnahme im Mittel 4920 U/1 gefunden, der Bereich umfaßte Werte von 1050 bis 20600 U/1 (18). Ein großer Teil dieser Seren wäre also mit dem sogenannten turbidimetrischen Test von vornherein nicht zu analysieren. Setzten wir Serumverdünnungen in physiologischer $\mathrm{NaCl}$-Lösung in den Test ein, so war bei den meisten untersuchten frischen Seren unabhängig von der Höhe der katalytischen Aktivität keine lineare Beziehung zwischen Meßsignal und Höhe der Verdünnung gegeben (s. Tab. 6). Da inaktiviertes Poolserum z.T. auch die bereits beschriebene Trübungszunahme zeigte, wurde es als Verdünnungsmedium von uns nicht benutzt. Das Problem der Analyse von Seren mit hoher katalytischer Aktivität im sogenannten turbidimetrischen Test ist also nach wie vor nicht gelöst.

Während bei dem kontinuierlichen titrimetrischen Verfahren infolge der hohen Trioleinkonzentration $98 \%$ der Maximalgeschwindigkeit erreicht werden, läuft die Enzymreaktion beim sogenannten turbidimetrischen Test nur mit etwa 7\% der maximalen Geschwindigkeit ab. Die gewählte Substratkonzentration liegt mit 0,079 $K_{\mathrm{m}}$ ganz am Anfang der Michaelis-Menten-Kurve und beträgt nur $0,2 \%$ der Trioleinkonzentration bei der Titrimetrie. Kleine Unterschiede in der Substratkonzentration ergeben daher im sogenannten turbidimetrischen Test große Abweichungen in der gemessenen katalytischen Aktivität. Die extrem niedrige Substratkonzentration führt weiterhin zu einem sèhr schnellen Substratumsatz bei der Analyse von Proben mit hoher katalytischer Aktivität. Mißt man in solchen Fällen nach Vorschrift -4 und 9 Minuten nach Start der Reaktion -, so kann es zum weitgehenden Verbrauch des Substrats vor Beginn der Messung und damit fälschlich zu normalen Befunden kommen. Das Problem ist auch von der Messung der Transaminasen her bekannt: Die hohen katalytischen Aktivitäten bei akuter Hepatitis werden öfters nicht erkannt, weil das NADH im Testansatz verbraucht ist, bevor die erste Messung erfolgt. Bei Einsatz eines Serums mit einer katalytischen Aktivität an Lipase von $12900 \mathrm{U} / \mathrm{l}$ in den sogenannten turbidimetrischen Test betrugen z.B. die gemessenen Änderungen des Meßsignals nach Start in den ersten Minuten: $0,296,0,202,0,085,0,026,0,010,0,006,0,005,0,003$, 0,002; bei Auswertung der Trübungsabnahme zwischen der 4. und 9. Minute errechnen sich 160 U/1. Möglicherweise ist die von Kreutzer et al. bei einem ihrer Patienten beobachtete Diskrepanz zwischen der auf das 5-fache der oberen. Normgrenze erhöhten Amylase und der nicht angestiegenen Lipase so zu erklären (Abb. $3 \mathrm{~B}$ in l.c. (10)). Ohne Frage hat es für den Patienten erhebliche klinische Folgen, wenn statt eines sehr hohen Ergebnisses ein solches herausgegeben wird, das im Referenzbereich liegt. In Bezug auf die Lipase sei hier nur an die
Bedeutung der Befunde bei der Differentialdiagnose des akuten Abdomens erinnert. Ein möglicher grober Fehler dieser Art läßt sich vermeiden, wenn man sich einen Uberblick über den gesamten Reaktionsablauf verschafft, indem längere Zeit in Minutenabständen abgelesen wird.

$\mathrm{Da}$ im sogenannten turbidimetrischen Test Triolein als Substrat verwendet und die Kalibrierung über einen Enzymstandard vorgenommen wird, dessen kataly tische Aktivität durch kontinuierliche Titration bestimmt wurde, wäre eine vollständige Übereinstimmung der so gewonnenen Ergebnisse mit denjenigen des titrimetrischen Tests zu erwarten. Vermutlich durch eine serumspezifische Trübungsreaktion werden jedoch im Einzelfall mehr oder weniger starke Abweichungen gefunden, so daß die Meßdaten der beiden Methoden signifikante, jedoch nicht systematische Unterschiede zeigen. Die von Beck-Oostendorp et al. (19) gefundenen systematischen Abweichungen beruhen darauf, daß bei der von den Autoren verwendeten Zweipunktme thode nach Weber mit dreistündiger Inkubation (20) (irrtümlich als Methode nach Rick bezeichnet!) nicht die Anfangsgeschwindigkeit der Triolein-Hydrolyse gemessen wird, so daß fälschlich zu niedrige katalytische Aktivitäten gefunden werden.

Wodurch die von Ziegenhorn et al. (3) beim titrimetrischen Verfahren im Vergleich zum sogenannten turbidimetrischen Test beschriebenen Restaktivitäten nach Inaktivierung von Serum bei $56^{\circ} \mathrm{C}$ zustandekommen sollen, ist unklar. Bei der Interpretation der angegebenen Żahlenwerte ist zu berücksichtigen, daß zwischen geringen katalytischen Aktivitäten und vollständiger Inaktivierung nur dann unterschieden werden kann, wenn das Auflösungsvermögen der Meßanordnung den bereits mitgeteilten Anforderungen (21) entspricht. Unter diesen Bedingungen (250 $\mu \mathrm{l}$-Bürette) entspricht $1 \%$ Bürettenvolumen pro Minute bei Einsatz von $1,0 \mathrm{ml}$ Serum einer katalytischen Aktivität von $25 \mathrm{U} / 1$. Verwendet man eine $1,0 \mathrm{ml}$-Bürette, so vermindert sich die Empfindlichkeit auf ein Viertel, 1\% Bürettenvolumen pro Zeiteinheit ergibt dann bereits eine katalytische Aktivität von $100 \mathrm{U} / 1$. Es ist zweifelhaft, ob mit einer derartigen Ausrüstung z.B. zwischen 16 bzw. $32 \mathrm{U} / 1$ (Tab. 2 aus 1.c. (3)) und Null differenziert werden kann. Außerdem ist unklar, wieso keinerlei Korrelation zu den Ausgangsaktivitäten vorliegt und gerade in dem Serum mit der höchsten katalytischen Aktivität (2984 U/1) (Tab. 2 aus 1.c. 3)) keine Restaktivität mehr gefunden wurde.

Da die Aktivität der Lipoproteinlipase im sogenannten turbidimetrischen Test nicht mitgemessen wird, ist diese Methode der Titrimetrie in der bisher publizierten Ausführung (21) an Spezifität überlegen. Wie erste Versuche zeigten, kann auch die Spezifität des titrimetrischen Verfahrens durch Einsatz höherer Gallensalzkonzentrationen bei Anwesenheit von Colipase gesteigert werden. Unter diesen Bedingungen wird die Lipoproteinlipase gehemmt, die Pankreaslipase jedoch nicht beeinflußt. 


\section{Schlußfolgerung}

Abschließend ist festzustellen, daß beim sogenannten turbidimetrischen Test Verbesserungen erforderlich sind, wenn damit im Einzelfall klinisch relevante Ergebnisse erzielt werden sollen.

Folgende Punkte erscheinen besonders wichtig:

1. Die meßtechnische Empfindlichkeit des Verfahrens sollte gesteigert werden.

2. Es ist erforderlich, minutenweise abzulesen, damit ein Überblick über die Änderung des Meßsignals gewonnen wird und fälschlich zu niedrige oder normale Ergebnisse aufgrund eines sehr schnellen Substratverbrauchs vermieden werden.

\section{Literatur}

1. Ziegenhorn, J., INeumann, U., Knitsch, K. W. \& Żweż, W. (1979) Clin. Chem. 25, 1067.

2. Deutsches Patentamt, Auslegeschrift 2904305.

3. Ziegenhorn, J., Neumann, U., Knitsch, K. W., Zwez, W., Roeder, A. \& Lenz, H. (1980) Medica 1, 919-925.

4. Prellwitz, W. (1980) pers. Mitteilung.

5. Fritsch, W.-P. \& Rick, W. (1974) Postheparinlipase. In: Methoden der enzymatischen Analyse (Bergmeyer, $H$. $U$. ed.). 3. Aufl. Verlag Chemie, Weinheim pp. 854-861.

6. Vogel, W. C. \& Zieve, L. (1963) Clin. Chem. 9, 168-181.

7. Shihabi, Z. K. \& Bishop, C. (1971) Clin. Chem. 17, 1150 $-1153$.

8. Verduin, P. A., Punt, J. M. H. M. \& Kreutzer, H. H. (1973) Clin. Chim. Acta 46, 11-19.

9. Ramiz, A., Nipper, H. C., Merchant, C. R. \& Knoblock, E. C. (1974) Z. Klin. Chem. Klin. Biochem. 12, 265.

10. Kreutzer, H. H., Pennings, A. W., Punt, J. M. H. M. . \& Verduin, P. A. (1975) Clin. Chim. Acta 60, 273-279.

11. Kok, P. J. M. J., Holtkamp, H. C. \& Seidel, B. (1978) Clin. Chim. Acta 83, 123-128.
3. Störungen durch Trübungszunahme im Test bzw. nicht linearen Reaktionsablauf, die bei mehr als $10 \%$ aller Seren eine Bestimmung der Lipase unmöglich machen, müssen eliminiert werden.

4. Die Testbedingungen sind so zu wählen, daß auch Verdünnungen von Seren hoher kataly tischer Aktivität untersucht werden können.

\section{Danksagung}

Wir danken Herrn Prof. Dr. H. U. Bergmeyer und Herrn Dr. J. Ziegenhorn für die freundliche Überlassung vơn Cólipase.

12. Zinterhöfer, L., Wardlâw, S., Jạtlow, P. \& Seligson, D. (1973) Clin. Chim. Acta 44, 173-178.

13. Proelss, H. F. \& Wright, B. W. (1977) Clin. Chem. 23, $522-531$.

14. Rick, W. \& Hockeborn, M. in Vorbereitung.

15. Yourno, J. \& Henưy, J. B. (1978) Aṃ. J. Clin. Pathol. $70,56-63$.

16. Yourno, J. \& Henry, J. B. (1978) Am̂̀. J. Clin. Pathol, 70, 64-70.

16a. Zwez, W., Hagen, A. \& Staehler, F. (1975) Clin. Chẹm. 21, 948.

17. Lorentz, K. \& Flatter, B. (1980) Med. Lab. 33, 236-239.

18. Rick, W. (1968) Verh. Dtsch. Ges. Inn. Med. 74, 230-233.

19. Beck-Oostendorp, E., Köchli, H. P., Degiampietro, P. \& Colombo, J. P. (1981) Med. Lab. 34, 77-82.

20. Weber, H. (1965) Dtsch. Med. Wochenschr. 90, 1170-1174.

21. Rick, W. (1976) Lipase. In: Handbuch der Inneren Medizin (Forell, M. M. ed.). 5. Aufl., Bd: Iili/6: Pankreas. Springer, Berlin pp. 350-361.
Prof. Dr. W. Rick Institut fiir Klinische Chemie und Laboratoriumsdiagnostik der Universität Düsseldorf Moorenstraße 5 D-4000 Düsseldorf 1 